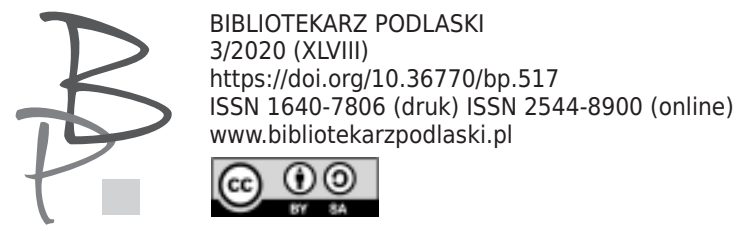

Krystyna Jaworska*

Università di Torino, Włochy

https://orcid.org/0000-0002-0706-9313

\title{
Brakujące kartki. Kłopoty z biografistyką emigracyjną na podstawie kilku kwerend, czyli zmagania ze scalaniem źródeł
}

Missing cards. Problems with emigration biographies, based on several queries, or struggles with merging sources

Abstract: The paper focuses on the difficulties underlying the research on some aspects of Polish history and literature abroad, due the high dispersion of documentary materials and pointing out how unusual, perilous, and accidental their survival sometimes was. In order to exemplify this the author reconstructs the story behind three postcards sent from Poland to Italy in the last century, one connected with the presence of a Polish Army Camp in Piedmont in 1919, addressed to the future Polish Honorary Consul in Turin Attilio Begey and the other two sent by a well-known poet, Kazimiera Iłakowiczówna, to his daughter Maria Bersano Begey. Those postcards luckily did not get loose thanks to a Polish émigré, Wojciech Fudakiewicz, who bought them from a bouquiniste.

Keywords: emigration, cards, biography, Polish history.

Krystyna Jaworska - prof. Uniwersytetu w Turynie, polonistka urodzona we Włoszech, zajmuje się głównie XIX i XX-wieczną literaturą emigracyjną oraz poezją współczesną. W 2019 roku wydała monografię Dalla deportazione all'esilio. Percorsi nella letteratura polacca della seconda guerra mondiale. 
Parę lat temu pokazano mi kilka pocztówek wysłanych w pierwszej połowie XX wieku z Polski do Turynu. Na jednej z nich widać plac, chorągwie, wojsko i tłum ludzi zwróconych ku balkonowi budynku reprezentacyjnego, z którego przypuszczalnie ktoś przemawia. Na kartce, na wolnej przestrzeni znajdującej się na ulicy, którędy wśród tłumu przechodził pochód wojskowy, ktoś dopisał odręcznie Entrata del gen. Haller in Torun polacca (wejście gen. Hallera do polskiego Torunia).

Pocztówkę zaadresowano do adw. Attilia Begeya. Treść kartki napisana jest tą samą ręką co adres, ale wygląda to na inne pismo niż to na froncie. Warto zauważyć, że nazwę Toruń pozbawiono znaku diakrytycznego, co może oznaczać, iż piszący nie był Polakiem. Wynika to też z samego tekstu: „26.I.1920, Torun. Inviamo all'Eg. Avv. Console della Polonia i nostri più cordiali saluti - da questa città ritornata attualmente ai Polacchi" (wysyłamy Sz. Panu Adw. Konsulowi Polski nasze najserdeczniejsze pozdrowienia - z tego miasta, które obecnie zostało zwrócone Polakom) i podpis [pierwsza litera nieczytelna] erica Bonicatti”.

Niżej, jeszcze innym charakterem pisma, widnieje informacja: „Rita e Carlo Golachowski con la piccola Wanda" (Rita i Karol Golachowski z małą Wandą). Następnie adres nadawcy z niemiecką jeszcze nazwą ulicy w Toruniu. $\mathrm{Na}$ kartce brak znaczka, najwyraźniej został odklejony.

Dla badaczy stosunków polsko-włoskich nazwisko Begeya jest dobrze znane: był to zwolennik Mazziniego, towiańczyk i bardzo zasłużony polonofil ${ }^{1}$. Podczas pierwszej wojny światowej założył w Turynie Komitet Pro Polonia, do którego wstąpiło wiele znanych osobistości, w tym kilku posłów i rektor turyńskiego uniwersytetu. Komitet wspomagał w miarę swych możliwości znajdujących się w bardzo trudnych warunkach bytowych przedstawicieli Polskiej Armii we Włoszech. Przebywali oni w założonym pod koniec 1918 roku w miejscowości La Mandria di Chivasso (około $30 \mathrm{~km}$ od Turynu) obozie dla byłych jeńców z armii austro-węgierskich, przyszłych Hallerczyków.

Warto zastanowić się nad tożsamością pani Bonicatti; nad tym, dlaczego znalazła się w 1920 roku w Toruniu, a także nad tym, kim byli Rita i Karol Go-

1 Zob. M. Sokołowski, Adwokat diabła Attilio Begey, Warszawa 2012. 
lachowski, gdyż mała Wanda to zapewne ich córka. Ponieważ kartka informuje o wkroczeniu Armii Hallera, łatwo wywnioskować, że pani Bonicatti była albo mieszkającą w Toruniu znajomą Begeya, albo była jakoś związana z obozem w La Mandrii. I faktycznie, wystarczy przejrzeć gazetę wydawaną w Turynie przez dowództwo Armii Polskiej we Włoszech „Żołnierz Polski we Włoszech” (pierwsze wydawane po polsku we Włoszech czasopismo, którego egzemplarze zachowały się do dziś) $)^{2}$, aby znaleźć zdjęcie por. Karola Golachowskiego ${ }^{3}$. Po powrocie kap. Mariana Dienstl-Dąbrowy do siedziby polsko-francuskiej Misji Wojskowej w Rzymie, to on został mianowany komendantem obozu.

Jeszcze w latach siedemdziesiątych ubiegłego stulecia myślano, że egzemplarz „Żołnierza Polskiego we Włoszech” przechowywany w Bibliotece Instytutu Kultury Polskiej im. Attilia Begeya, będącą obecnie częścią Biblioteki Departamentu Języków Obcych Uniwersytetu w Turynie, jest jedynym ocalałym. Przekonywał o tym Stanisław Sierpowski ${ }^{4}$, największy ówczesny znawca związków polsko-włoskich. Dopiero ulepszony w dobie cyfryzacji przepływ informacji uwidocznił, że zachowały się też inne komplety, dostępne współcześnie w Bibliotece Wojskowej w Warszawie, Bibliotece Polskiej w Paryżu oraz w kilku innych zbiorach.

Ale kim jest Rita? Aby się czegokolwiek o niej dowiedzieć, należy zajrzeć do prasy włoskiej tego okresu. W numerze czasopisma „Illustrazione dell’Esercito e dell'Armata" podano wiadomość o ślubie komendanta polskiego obozu z panną Ritą Bonicatti; do notki załączono zdjęcie młodej pary ${ }^{5}$. Artykuł wymienia obecnych na ślubie, w tym siostrę panny młodej o nietypowym imieniu Serica (słowo to po włosku znaczy ,,jedwabna”), a zatem nieczytelna litera imienia osoby piszącej kartkę to „S”. Była to siostra pani Golachowskiej, która być może pojechała do Torunia, aby pomóc Ricie przy pielęgnacji noworodka.

Następny fragment to opis grobu płk. Golachowskiego „Karol Golachowski lies buried in Auchinleck cemetery, Auchinleck, Scotland. Date of death -

2 J. Skrzypek, Tygodnik «Żotnierz polski we Włoszech»w $1919 r$., „Rocznik Historii Czasopiśmiennictwa Polskiego" 1972, XI, nr 1, s. 39-48; K. Jaworska, ,'Żotnierz polski we Włoszech" - polskie czasopismo w Piemoncie w 1919 roku, „Postscriptum” 2007 /1 (53), s. 161-171.

3 „Żołnierz polski we Włoszech”, nr 11-12, 19.06.1919, s. 1.

4 S. Sierpowski, Powstanie Armii Polskiej we Włoszech w czasie pierwszej wojny światowej, „Roczniki Historyczne” 1976, XLII, s. 83.

5 „Illustrazione dell'Esercito e dell'Armata” 1919, nr 3, s. 15. 
31 October 1948 Age - 60"6. Z załączonego zdjęcia wynika, że służył on w Polish Resettlement Corps. Ze strony internetowej My Herytage można się dowiedzieć, że jego żona zmarła w 1967 roku$^{7}$. Prawdziwą niespodzianką jest jednak artykuł ze strony internetowej miasta Toruń z 9 grudnia 2019 roku. Okazuje się, że Wanda Golachowska poprzedniego dnia obchodziła setne urodziny.

Spotkanie urodzinowe odbyło się w niedzielę 8 grudnia 2019 roku w Casa Bonicatti, restauracji, której nazwa jest panieńskim nazwiskiem matki Pani Wandy. Stulatka bowiem urodziła się 8 grudnia 1919 w Skierniewicach, jej ojciec, Karol Golachowski, był Polakiem, oficerem, Hallerczykiem, uczestnikiem pierwszej i drugiej wojny światowej, matka zaś, Margherita z domu Bonicatti - Włoszką, córką przemysłowca z Turynu.[...]

Kiedy pani Wanda miała dwa lata, rodzina zamieszkała w Toruniu [...]. Maturę Wanda zdała w Warszawie, gdzie rodzice się przeprowadzili w 1936 roku.

W grudniu 1939 roku pani Wanda z matką Margheritą i młodszym bratem Karolem wyjechała do dziadków do Włoch. Tam wyszła za mąż, urodziła syna i mieszkała do lat 80. zeszłego stulecia, podczas gdy mama i brat wrócili do Polski po wojnie. Wanda odwiedziła Polskę pierwszy raz dopiero w 1986 roku. Była to kilkudniowa wizyta w Warszawie u brata Karola.

W 1976 roku Wanda przypadkowo poznała we Włoszech Polki, siostry Magdę i Ewę, od tego dnia jej życie jest znów związane z Polską. [...] Znów zamieszkała w Toruniu w należącej do swoich rodziców kamienicy przy ul. Żeglarskiej8.

$6 \mathrm{http}: / /$ www.derekcrowe.com/poland/wargraves/photo.aspx?id=1111

7 Ze strony dowiadujemy się ponadto, że płk. Karol Golachowski urodził się w Krakowie 27 maja 1888 oraz że żona Margherita Bonicatti zmarła w 1967 roku, mając 87 lat. https://www. myheritage.it/names/karol_golachowski

8 UM Toruń, Dużo zdrowia, Pani Wando, https://www.torun.pl/pl/duzo-zdrowia-pani-wando; https://halotorun.pl/20191209256637/um-torun-duzo-zdrowia-pani-wando-1575855566. Nastronie restauracji Casa Bonicatti czytamy: „Margherita, powróciwszy do Torunia po zakończeniu wojny odkryła, że już niczego nie posiada. Przez kilka lat mieszkała w kamienicy na ulicy Żeglarskiej jako zwykła lokatorka, ale z powodu wieku i choroby musiała ostatecznie powrócić do Turynu, gdzie córka się nią zaopiekowała. [...] Córka Margherity - Wanda, będąca jej jedyną spadkobierczynią, odzyskała prawo własności do kamienicy na ulicy Żeglarskiej w 2008 roku". http://casabonicatti.pl/ kes-histori/ 
$\mathrm{Na}$ stronie restauracji prowadzonej przez przyjaciół pani Bonicatti umieszczono informację, że podczas II wojny światowej Karol został „najpierw wysłany do Paryża, a potem na front”, że „zaginął w Anglii” i że kamienica rodziców Wandy Golachowskiej została przez nią odzyskana w 2008 roku. Pozostaje do sprawdzenia fakt, jaką drogą płk Golachowski trafił do Anglii, czy prosto z Paryża, jak wielu Hallerczyków, czy był wysłany do 2 Korpusu lub walczył w Dywizji Maczka - mowa wszak o tym, że był na froncie.

Do Anglii trafiła też kartka wysłana z Torunia do Turynu, ale całkiem inną drogą. Przywiózł ją „londynczyk”, pan Wojciech Fudakowski. Podczas podróży do Włoch znalazł ją bowiem pod koniec lat siedemdziesiątych lub na początku osiemdziesiątych wraz z kilkoma innymi materiałami u bukinisty na placu nieopodal dworca w centrum Turynu. Pocztówek z Polski było tam sporo i wybrał te, które wydały mu się najbardziej interesujące. Pan Fudakowski, żołnierz AK, który po wojnie osiadł na stałe w Londynie, brał czynny udział w życiu emigracji niepodległościowej, będąc między innymi powiernikiem w Instytucie Polskim i Muzeum gen. Sikorskiego, gdzie zresztą miałam wielką przyjemność poznać go osobiście. Dowiedziawszy się, że mieszkam w Turynie, pokazał mi pocztówki.

Kiedy zobaczyłam adresata, zaczęłam opowiadać o Begeyu i jego działalności propolskiej, zapoczątkowanej jeszcze w 1863 roku i kontynuowanej przez całe życie. Za swoje zasługi po pierwszej wojnie światowej został on mianowany konsulem honorowym RP. Begey umiał przekazać miłość do Polski rodzinie i znajomym, dzięki czemu w Turynie zawiązało się grono osób zajmujących się kulturą polską. Był to podatny grunt do stworzenia ośrodka i z tej racji w 1930 roku, dwa lata po śmierci Begeya, powstał przy Uniwersytecie w Turynie Instytut Kultury Polskiej jego imienia. Wraz z katedrą języka i literatury polskiej na Uniwersytecie La Sapienza w Rzymie to najstarsza akademicka placówka polonistyczna we Włoszech i niewątpliwie jedna z najbardziej zasłużonych.

Pan Fudakowski wspomniał, że czytał w wydawanym w Londynie „Tygodniku Polskim" artykuł Zofii Kozarynowej na temat udziału zacnej polonistki Mariny Bersano Begey w akcji wysyłania paczek do Polski po wprowadzeniu

9 Krótkie wspomnienie o inż. Wojciechu Fudakowskim (Warszawa 1927-Londyn 2016)jest umieszczone na stronie Fundacji Veritas: https:/www.veritasfoundation.co.uk/gazetaniedzielna/2016/05/5237/ 
stanu wojennego w 1981 roku i przyniósł mi wycinek tego artykułu ${ }^{10}$. W rozmowie wspomniał, że czytał też artykuł Kozarynowej o Clotildzie Garosci. Nigdy na ten artykuł bym nie trafiła bez życzliwości pana Fudakowskiego.

Zofia Kozarynowa była lektorką języka polskiego na Uniwersytecie w Turynie w latach 1929-1939. Zaprzyjaźniła się wówczas z rodziną Agosti Garosci. Clotilde Garosci i Cristina Agosti Garosci zainteresowały się Polską podczas pierwszej wojny i wstąpiły do Komitetu pro Polonia, możliwe że dzięki córce Attilia Begeya, Marii Bersano Begey, która była członkinią, jak siostry Garosci, prestiżowego stowarzyszenia Pro Cultura Femminile. Nauczyły się języka polskiego i zaczęły tłumaczyć dzieła literatury polskiej, w tym Mickiewicza, Sienkiewicza, Konopnickiej i Żeromskiego na włoski ${ }^{11}$.

Kozarynowa powróciła do Turynu po wojnie, ale tylko na chwilę, gdyż pragnęła się połączyć z córką w Wielkiej Brytanii ${ }^{12}$. Prof. Bersano Begey miała do niej z tego powodu żal, bo z wielkim trudem udało jej się uzyskać zgodę władz warszawskich na wyjazd pani Kozarynowej jako lektora do Włoch, podczas gdy turyńska uczelnia zgodziła się pokrywać jej wynagrodzenie. Z powodu wyjazdu do Anglii Zofii Kozarynowej polonistyka turyńska straciła na długie lata lektorat, a to dlatego, że - zwłaszcza po wyjeździe ambasadora Kota - prof. Bersano Begey nie starała się o względy Ambasady PRL we Włoszech.

W „Tygodniku Polskim” pod datą 11 października 1991 roku Kozarynowa wspomina, że otrzymała w Wielkiej Brytanii od rodziny Agosti Garosci kufer z rzeczami, które pozostawiła w Turynie:

10 Z. Kozarynowa, Nakarmione dzieci, „Tydzień Polski”, 06.06.1982, s. 7.

11 Ostatnio pojawiło się kilka prac na temat działalności translatorskiej sióstr Garosci, w tym Cristina Agosti Garosci (1881-1966), opr. M. Sokołowski, ,pl.it. Rassagna italiana di argomenti polacchi" 2013, s. 14-17, https://plitonline.it/pdf/2013/plit-4-2013-14-34-cristina-agosti-garosci-mikolaj-sokolowski.pdf; tenże, Iridione di Zygmunt Krasiński il contesto ideologico della traduzione italiana, „Kwartalnik Neofilologiczny” 2014 LXI, nr 2, s. 357-365; A. Amenta, Le sorelle Garosci traduttrici dal polacco, [w:] Maestri della polonistica italiana. Atti del convegno dei polonisti italiani, opr. M. Ciccarini i P. Salwa, Accademia Polacca delle Scienze Biblioteca e Centro di Studi a Roma, Roma 2014, s. 27-35, http://www.rzym.pan.pl/images/files/conferenze/Conferenze_129_Maestri.pdf; S. Skuza, Cristina Agosti-Garosci i Clotilde Garosci-zapomniane tlumaczki największych dziet literatury polskiej na język włoski, „Rocznik Przekładoznawczy” 2018, nr 13, s. 213-224, https://apcz. umk.pl/czasopisma/index.php/RP/article/view/RP.2018.012/15236.

12 Kozarynowa opisuje migawki z okresu turyńskiego w swych wspomnieniach Sto lat. Gawęda o kulturze środowiska, Londyn 1982, s. 158, 218-220, 228-229, 269, 275, 277. 
$\mathrm{Na}$ wierzchu leżały dwie wielkie koperty z moimi własnoręcznymi napisami. $\mathrm{Na}$ jednej: „Fotografie z obozu jeńców polskich z wojska austriackiego (1919) w La Mandria di Chivasso pod Turynem (1919) (bez nazwisk). Pamiątki zachowane przez Clotilde Garosci”. Na drugiej zaś kopercie: „Szarfy z bukietu pożegnalnego, ofiarowanego Kloyildzie Garosci przez grono od oficerów polskich, opuszczających obóz jeńców w La Mandria di Chivasso". Skromne są to pamiątki. Garść listów i kartek z okolicznościowymi życzeniami. Afisze i programy obozowych występów amatorskich, lokalne znaczki pocztowe o symbolicznej, przelotnej wartości [... $]^{13}$.

Kozarynowa opowiada w charakterystycznym, gawędziarskim stylu, że niezbyt przystojną Klotyldą zainteresował się por. Stromenger ze Lwowa. Po wyjeździe armii spodziewała się od niego listów, tymczasem ,„przez czas jakiś dochodziły grupowe kartki z zamaszystymi i nieczytelnymi podpisami”, aż stopniowo korespondencja wygasła.

Aby więc dotrzeć do tych „skromnych pamiątek”, które dziś miałyby dużą wartość, dobrze byłoby zapoznać się z materiałami pozostałymi po Zofii Kozarynowej. Ponieważ zamieszkała ona na stare lata w Domu Polskim w Laxton Hall, zapytałam Dyrektor Archiwum Polskiej Misji Katolickiej Jadwigę Kowalską, czy są tam papiery pani Kozarynowej. Otrzymałam odpowiedź negatywną. Niewykluczone, że jest w ich posiadaniu mieszkająca na stałe w USA jej córka. Dlatego dalsze poszukiwania należałoby prowadzić w tym właśnie kierunku. Bardziej owocna, choć w minimalnym stopniu, okazała się kwerenda w Bibliotece Polskiej POSKu w Londynie: w papierach Zofii Kozarynowej, tu deponowanych, są też notatki do artykułu o Klotyldzie Garosci, napisane już bardzo niepewnym pismem. Jest też kilka zdań nieco różniących się od treści wydanej drukiem i kilka dodatkowych informacji, ale żadnych pamiątek ${ }^{14}$.

W albumie fotograficznym Armii Polskiej we Włoszech, podarowanym Attiliowi Begeyowi, a przez jego wnuczkę przekazanym do Muzeum Narodowego Włoskiego Risorgimento, znalazło się kilka luźnych zdjęć oficerów tejże armii z dedykacją dla Begeya. Wśród nich jest też zdjęcie Strumengera ${ }^{15}$.

13 Z. Kozaryn, Jeden dzień w życiu Klotyldy, „Tydzień Polski”, 19.10.1991, s. 7 i 12.

14 Zespoły rękopisów Biblioteki Polskiej POSK w Londynie: Zofia Kozarynowa, sygn.3.45.

15 Reprodukcja tego zdjęcia [w:] K. Jaworska, Da prigionieri a uomini liberi. L'Armata Polacca in Italia 1918-1919. Z niewoli do niepodległości. Armia Polska we Wtoszech 1918-1919, Torino, Celid, 2018, s.92. 
Nie wiadomo, jak potoczyły się dalsze losy Strumengera. Być może jakieś na ten temat materiały przechowuje rodzina Cristiny Agosti Garosci? Jej wnuczka, znana fotografik, skrupulatnie przechowała wszystko, co do niej dotarło. Jednakże żadnej korespondencji swojej babci, ani jej siostry, ona nie ma. Jedyne warte uwagi materiały to listy jej ojca Giorgia Agosti do matki, pisane po włosku z Zakopanego i zawierające wrażenia z pobytu w Polsce ${ }^{16}$. W Zakopanem młody Agosti uczestniczył w kursie dla włoskich polonistów, organizowanym przez niestrudzonego Romana Pollaka, który przyczynił się do powstania i rozwoju polonistyki uniwersyteckiej we Włoszech w okresie międzywojennym, po uznaniu przez rząd włoski państwa polskiego ${ }^{17}$.

Wśród kartek wykupionych u bukinisty przez Wojciecha Fudakowskiego są też dwie pocztówki Kazimiery Iłłakowiczówny adresowane do córki Attilia Begey, Marii Bersano Begey. Ile jeszcze kartek trafiło do rąk zbieraczy ze względu na ich atrakcyjny wygląd, a nie ze względu na korespondentów? Co się z nimi stało? Co z listami, które przypuszczalnie były przechowywane wraz z kartkami? W domu Begeya w górach w letniskowej miejscowości Viù, który córka Marii Bersano Begey, Marina, pozostawiła w spadku swemu bratankowi, były też różne polonika (w tym piękna XIX-wieczna reprodukcja obrazu Matki Boskiej ostrobramskiej) oraz sporo egzemplarzy włoskich wydań pism Towiańskiego i towiańczyków.

Niestety, po śmierci pani Profesor próby dotarcia do tych materiałów okazały się próżne. Na wysyłane pytania, czy w Viù przechowywane są jakieś książki lub listy po polsku, odpowiedź otrzymałam negatywną, a kilka lat temu, po kolejnych pytaniach, pojawiła się informacja o tym, że niestety dom letni został splądrowany przez złodziei. Pozostaje zagadką, jak to się stało, że pocztówki trafiły do bukinisty o wiele wcześniej. Z korespondencji Begeya uratowało się wyłącznie to, co prof. Bersano Begey przesłała wraz z cen-

16 Giorgio Agosti (1910-1992) pod wpływem atmosfery rodzinnej podczas studiów uczył się polskiego i napisał pracę magisterską na wydziale prawa o Fryczu Modrzewskim, na podstawie której wydał artykuł. W latach trzydziestych napisał jeszcze kilka innych tekstów o polskiej myśli politycznej w XV i XVI wieku.

17 Świadczy o tym także wieloletnia korespondencja Pollaka z pierwszym profesorem literatury polskiej w Rzymie: Roman Pollak - Giovanni Maver. Korespondencja (1925-1969), opr. M. Rabenda, Poznań 2013. 
nymi przedmiotami i pamiątkami związanymi z Towiańskim i jego kręgiem (w tym obraz pędzla Walentego Wańkowicza) do Muzeum Literatury im. Adama Mickiewicza w Warszawie ${ }^{18}$ (w tym listy do Attilia Begeya od Władysława Mickiewicza i Mariana Zdziechowskiego) oraz wybrana korespondencja do Begeya po włosku, która została przez nią przekazana wraz z archiwum Sprawy Bożej Towiańskiego (zawierającego także listy Adama Mickiewicza ${ }^{19}$ ) do Biblioteki Królewskiej w Turynie ${ }^{20}$.

Wróćmy jednak do pocztówek Iłłakowiczowiczówny. W obu występują ilustracje polskich strojów ludowych. Znaczki odklejone (jak w wypadku kartki z Torunia), co ma tu większy skutek ujemny, ponieważ jedna pocztówka jest niedatowana. Tekst jest następujący:

Chère Madame, il m'est difficile de dire combien de plaisir et de bonne humeur ma pauvre soeur a puisé dans ce livre béni de Guareschi que vous m'avez envoyé. Ma nièce cadette a entrepris de peindre al fresco toute une église de campagne non loin de Varsovie. Et vous, chère amie?

Mille benedictiones, $\mathrm{KI}$

Droga Pani, trudno mi wyrazić ile przyjemności i dobrego humoru moja biedna siostra czerpała z tej błogosławionej książki Guareschiego, którą mi Pani przysłała. Moja najmłodsza siostrzenica postanowiła namalować freskiem cały wiejski kościół niedaleko Warszawy. Co na to, droga Przyjaciółko?

Tysiąc błogosławieństw, KI

A oto tekst drugiej pocztówki:

29 VII 1957

Chère Amie, y avait - il quelque livre sur le Père Pio qui - parait il - est tellement saint. Je crois que cela pourrait faire du bien à ma pauvre soeur. Auriez Vous la

18 J. Odrowąż-Pieniążek, Polonika zbierane po świecie, Warszawa 1992, s. 7-14.

19 Listy te ukazały się zarówno w wydaniu narodowym (1955), jak też w wydaniu rocznicowym (2003-2004) Dzieł Mickiewicza.

20 K. Jaworska, L'archivio Begey. Documenti towianisti a Torino 1841-1915, Torino, Biblioteca Reale-Celid, 1994. 
bonté angélique de m'en procurer, si cela existe. En italien, évidemment. Mille bonnes pensées,

Casimire Iłakowicz

Droga Przyjaciółko, czy byłaby jakaś książka o Ojcu Pio, który - jak się wydaje jest tak święty. Myślę, że to może zrobić dobrze mojej biednej siostrze. Czy posiada Pani anielską dobroć, aby mnie ją sprawić, o ile takowa istnieje? Oczywiście po włosku. Tysiąc dobrych myśli,

Kazimiera Iłłakowicz.

Na reprodukcji, którą otrzymałam, podpis na samym dole jest ucięty, ale można go rozszyfrować, znając charakterystyczny sposób podpisywania się pisarki.

Obecność tych kartek nie jest wyrazem efemerycznej znajomości. Wręcz przeciwnie, stanowią one ostatni ślad korespondencji, która toczyła się przez ponad ćwierć wieku, od kiedy córka Attilia Begeya, zarażona miłością do Polski przez ojca, na początku lat trzydziestych wzięła się do przekładu Historii moskiewskiego męczeństwa ${ }^{21}$. Jest to wiersz Iłłakowiczówny wydany w 1927 roku, wzorowany (jak napisała sama autorka) na stylu średniowiecznych ludowych tekstów religijnych, poświęcony ks. Konstantemu Budkiewiczowi, aby ułatwić jego drogę do beatyfikacji22. Ale skąd piemoncka polonistka znała ten wiersz? Przydałyby się szersze źródła archiwalne, aby wyjaśnić tę sprawę. Możliwe, że dowiedziała się o nim od córki Mariny, która studiowała dwa lata na Uniwersytecie Jagiellońskim. Możliwie również, że dowiedziała się o nim dzięki lektorkom języka polskiego oddelegowanym do Instytutu Begeya z Ministerstwa Wyznań Religijnych i Oświecenia Publicznego; były to początkowo w 1928 roku Zofia Gąsiorowska-Szmydtowa, po niej Zofia Kozarynowa.

Na szczęście szereg listów i kartek Iłłakowiczówny (nie wiemy jednak, czy to całość korespondencji) prof. Marina Bersano Begey nie pozostawiła w Viù, ale zabrała ze sobą do mieszkania pod Turynem, w Pino Torinese. Zostały mi one przekazane wraz z archiwum Instytutu Kultury Polskiej im. Attilio Begey po

21 K. Iłłakowicz, Storia del martire di Mosca, opr. i thum. Marii Bersano Begey, „Convivium” 1931, s. 835-854.

22 Zob. M. Babraj, „Trzeba wciąz przypominać światu”. W siedemdziesiąta rocznice męczeństwa ks. prałata Konstantego Budkiewicza, „W Drodze” 1993, 3 (235), s. 72, na s. 74-81 przedruk wiersza Iłłakowiczówny: http://bc.dominikanie.pl/dlibra/plain-content?id=907 
jej zgonie przez jej brata, który był wykonawcą testamentu. Archiwum Instytutu zostało zdigitalizowane przez dr Sylwię Szarejko i posłużyło jej, wraz z Archiwum Ogniska Polskiego w Turynie, do napisania pracy doktorskiej.

Z myślą o opracowaniu korespondencji Iłłakowiczówny z Marią Bersano Begey, zwróciłam się do Biblioteki Kórnickiej PAN, gdzie są zdeponowane papiery poetki. Wszystko jest tam dokładnie skatalogowane, a katalog udostępniono online, zatem poszukiwanie było błyskawiczne23. Dzięki uprzejmości tamtejszego bibliotekarza, pana Grzegorza Kubackiego, otrzymałam również błyskawicznie skany listów od Marii Bersano Begey do poetki. Zachowało się 11 listów powojennych: wcześniejsze musiały zaginąć w zawierusze wojennej w Warszawie, brak również listów z okresu, kiedy Iłłakowiczówna była w Rumunii. Wydaje się więc, że nie przywiozła ich ze sobą do Polski.

W Pino Torinese znalazły się bruliony 5 przedwojennych listów wysłanych przez Marię Bersano Begey oraz 26 listów i kartek Iłłakowiczówny do Marii Bersano Begey, niektóre pełne wdzięczności i życzliwości. Pisze na przykład poetka 28 grudnia 1953 roku z Poznania: „Vous êtes si bonne, si intelligente, si aimable que j'aimerais savoir un peu plus sur vous" (Pani jest taka dobra, taka inteligentna, taka miła, iż pragnęłabym wiedzieć coś więcej o pani). Korespondentki znały się głównie z listów (Iłłakowiczówna miała przyjechać z cyklem konferencji do Włoch, w tym do Turynu, na zaproszenie Instytutu Kultury Polskiej im. A. Begeya w 1939 roku, lecz przyjazd ten nie doszedł do skutku²4), ale z ich tonu wynika, że łączyła je przyjaźń oraz wiara, jak również wspólne zainteresowanie malarstwem o tematyce religijnej.

Wydano w ostatnich latach sporo listów Iłłakowiczówny, jak również wiele na ten temat pisano ${ }^{25}$. $\mathrm{Z}$ indeksu osobowego w pokaźnym tomie li-

23 Katalog Rękopisów Biblioteki Kórnickiej BK 12067, Iłłakowiczówna Kazimiera, Korespondencja. kop. 1948-1982, Listy od następujących, Bersano Begey Maria 1950-1953 (11), przy tym fot., koperta i francuskie thumaczenia wierszy. http://baza1-bis.man.poznan.pl/cgi-bin/ makwww.exe?BM=07\&IM=12\&WI=BKb12067\&NU=01\&DD=1

24 M. Bersano Begey, Attività dell'Istituto di Cultura polacca A. Begey negli anni 1940-1945 (Sprawozdanie z działalności Instytut Kultury Polskiej im. A. Begeya za lata 1940-1945), s. 1, maszynopis przechowywany w Archiwum Instytutu.

25 R. Jędrzejewska-Wróbel, Potykając się o ciemność. Powojenna korespondencja Kazimiery Itłakowiczówny, [w:] Z cienia niepamięci do światta: Wojciech Bąk, Kazimiera Itłakowiczówna, Roman Brandstaetter, red. E. Krawiecka, Poznań 2006; wymienia się tutaj wśród korespondentów takie potaci, jak Pola Gojawiczyńska, Anna Kowalska, Maria Dąbrowska, Maria Niklerowiczowa, $\rightarrow$ 
stów do siostry wynika, że w niektórych tekstach pojawia się Maria Bersano Begey. Okazuje się jednak - w trakcie ich lektury - że są to raczej przelotne zdania i to właśnie w związku z wysłanymi książkami. Słowa zachwytu i przyjaźni skierowane do turyńskiej polonistki były raczej grzecznościowe, tym bardziej, że w liście do siostry, napisanym 7 czerwca [1957 roku] w związku z książką Guareschiego, czytamy: „Z Guareschim musi zachodzić jakieś zabawne nieporozumienie [...]. Musiałam coś poplątać albo ja, albo ta stara Włoszka"26, trudno zastosowany przymiotnik uznać za dowartościowujący. List ten jednak pozwala na orientacyjne datowanie pocztówki do Marii Bersano. Urodzona w 1879 roku w Turynie, ta „stara Włoszka” była około dziesięć lat starsza od poetki (która, mimo że odejmowała sobie lata, nie była najmłodsza) i zmarła 18 lipca 1957 roku, a zatem nie przeczytała już kartki napisanej przez Iłłakowiczównę z prośbą o książkę Padre Pio. Po jej śmierci poetka jeszcze przez krótki okres pozostawała w kontakcie z jej córką Mariną ${ }^{27}$.

Jak wiadomo, Iłłakowiczówna skrupulatnie dbała o własny wizerunek, selekcjonując listy do przechowywania ${ }^{28}$, starannie wybierając to, co ma pisać, ze stylizowaną skromnością i poczuciem subtelnego humoru przedstawiając się w swych wspomnieniach z różnych okresów życia. Do tego autoportretu, lub autokreacji, Maria Bersano Begey była widocznie zbędna. Rozbieżność pojawiająca się pomiędzy zwrotami do korespondentki a sposobem jej określania w liście do siostry wskazują nie tyle na złożoną osobowość autorki, ile na różne konwencje stosowane w komunikacji interpersonalnej w zależności od adresata lub czytelnika.

$\rightarrow$ Maria Czapska, Joanna Kulmowa; Monika Chuda; Z adresownika poetki. Śladami listów Kazimiery Itłakowiczówny w bibliotekach polskich, „Biblioteka” 2010, nr 14 (23), s. 201-213; korespondentów jest sporo, jak wynika z katalogu Biblioteki Kurnickiej; zob też spis listów w Bibliografii umieszczonej [w:] K. Iłłakowiczówna, Poezje zebrane, opr. J. Biesiada, A. Żurawska-Włoszczyńska, t. 4, Toruń, 1999, s. 571-573.

26 K. Iłłakowiczówna do B. Czerwijowskiej, [Poznań] 7 czerwca [1957], [w:] K. Iłłakowiczówna, Listy do siostry Barbary Czerwijowskiej z lat 1946-1959, oprac., wstęp i przypisy L. Marzec, Poznań 2014, list 310, s. 326.

27 W liście do siostry z 11 sierpnia 1958 roku wspomina, że od „Mariny Begey, lektorki polskiego w Turynie”, (w rzeczywistości jeszcze przed wojną Marina miała już tytuł wolnego docenta) otrzymała żywot Kosmy i Damiana, dz. cyt., list 407n.

28 L. Marzec, Archiwum jako pisarski testament i depozyt legendy biograficznej, „Teksty Drugie" 2018, nr 6, s. 231-248. 
Byłoby jednak krzywdzącą redukcją ocenianie korespondencji z włoską badaczką tylko z powyższej perspektywy, ponieważ zawiera ona szereg ciekawych wątków. Pozwala między innymi zastanowić się nad koncepcjami i literackimi zabiegami, jakie podjęła autorka w Historii moskiewskiego męczeństwa oraz nad kryteriami zastosowanymi w przekładzie, aby oddać dominanty stylistyczne oryginału. Pozwala zapoznać się z wyrażonymi refleksjami i samopoczuciem Iłłakowiczówny podczas wojennego pobytu w Rumunii, są tam wzruszające opisy ciężkiej sytuacji miejscowej ludności, które przy zestawieniu z wierszami im poświęconymi i opowiadaniami samej poetki, uzupełniają obraz tych lat. Listy napisane po powrocie do Polski świadczą z kolei o trudnościach, z którymi borykała się była sekretarz marszałka Piłsudskiego i o jej nigdy niestraconej wrażliwości do dzieł malarskich.

Jest to kolejne świadectwo przydatności zarówno korespondencji, jak i innych tekstów paraliterackich, do lepszego zrozumienia autora, a co za tym idzie, jego tekstów literackich. Kiedyś podchodziłam z pewnym zażenowaniem do czytania cudzej korespondencji, ponieważ wydawało mi się to lekko niestosowne, czymś w rodzaju wkradania się bez pozwolenia przez dziurkę od klucza w cudze życie. Z biegiem lat coraz bardziej mogłam się przekonać o ważności porównywania wzajemnie wielorakich gatunkowo źródeł, a zwłaszcza porównywania, jak podobne tematy są ujmowane przez tego samego autora $\mathrm{w}$ zależności od gatunku literackiego i od domyślnego czytelnika. Można by to określić jako coś w rodzaju mikrokomparatystyki wewnętrznej ${ }^{29}$ lub komparatystyki autorskiej, badającej różne źródła i formy wyrazu w twórczości tego samego pisarza i świadczącej o złożoności hermeneutyki tekstowej w dążeniu do odtworzenia wielowymiarowej przestrzeni wypowiedzi autorskiej.

Przez wiele lat biografistyka była uprawiana na marginesach literaturoznawstwa z powodu wielkiego wpływu strukturalizmu i poststrukturalizmu. Obecnie, po kolejnych -izmach (postmodernizmie, dekonstrukcjonizmie) następuje powrót do badań źródłowych i do biografistyki, o czym świadczy jeden

29 Wykorzystuję tu określenie Kwiryny Ziemby (Projekt komparatystyki wewnętrznej, „Teksty Drugie" 2005, 1-2, s. 72-82), odnoszący się do badań nad wielojęzykową spuścizną literacką Rzeczpospolitej Obojga Narodów, aby opisać porównanie różnic wyrażania podobnych pojęć w twórczości tego samego autora, w zależności od gatunku literackiego, którym posługuje się, od adresata i od biograficznych uwikłań i doświadczeń. 
z ostatnich numerów „Tekstów Drugich”, poświęcony biografistyce w nauce o literaturze ${ }^{30}$.

Ponieważ niniejszy tekst krąży wokół trzech kartek, które dzięki Wojciechowi Fudakowskiemu zostały uratowane i trafiły do Londynu, pragnę, pozostając na terenie Wielkiej Brytanii, wspomnieć o dotkliwych lukach w wiedzy dotyczącej szeregu postaci emigracyjnych, wynikających z fragmentaryczności lub szczupłości materiałów archiwalnych. Dotyczy to nie tylko papierów po Zofii Kozarynowej, ale bardziej jeszcze dotkliwie spuścizny archiwalnej takich autorów, jak Herminia Naglerowa, uważanej przed wojną za jedną z najwybitniejszych polskich powieściopisarek, stawianej obok Dąbrowskiej i Nałkowskiej, a prawie całkiem zapomnianej po wojnie w ojczyźnie ${ }^{31}$, z chwalebnych wyjątkiem Anny Wal, autorki ważnej monografii ${ }^{32}$ i kilku innych badaczy. Poza niewielkim zbiorem materiałów, który przechowuje Biblioteka POSKu, nie wiadomo, co się stało z resztą jej papierów. Trudne warunki bytowe na emigracji, zwłaszcza w pierwszych latach tułaczki, oraz niewątpliwie rozpacz, gorycz i smutek związane z powojennym losem Polski i własnym, nie sprzyjały, szczególnie w niektórych przypadkach, zabezpieczaniu zbiorów.

Wielokrotnie rozmawiałyśmy z Violettą Wejs-Milewską na temat tych i innych brakujących kartek. Żywię nadal mikroskopijną nadzieję, że przy porządkowaniu archiwum Tymona Terleckiego przez białostocki zespół, z kluczowym udziałem Niny Taylor-Terleckiej, może coś jeszcze się pojawi. A zatem można tylko się radować, że ten projekt badawczy doszedł do skutku i to nie tylko ze względu na szansę znalezienia ważnych papierów dotyczących emigracyjnych pisarzy, z którymi był on w kontakcie, ale przede wszystkim ze względu na wartość dorobku samego Tymona Terleckiego.

30 „Teksty Drugie” 2019, nr 1 zawiera m. in. na s. 181-194 recenzję L. Marzec (Biografia zza przyłbicy: Kazimiera Itłakowiczówna według Joanny Kuciel-Frydryszak) dotyczącą książki J. Kuciel-Frydryszak, Itła. Opowieść o Kazimierze Itłakowiczównie, Warszawa 2017.

31 Niestety, nawet po 1989 roku mało kto zajmuje się jej pisarstwem (uwagę zwrócił na tę sprawę ostatnio M. Kuba, Skazane na nieobecność, „Rzeczpospolita” 2019, nr 203, s. 7-8).

32 A. Wal, Wierna życiu i literaturze: o pisarstwie Herminii Naglerowej, Rzeszów 2014. 

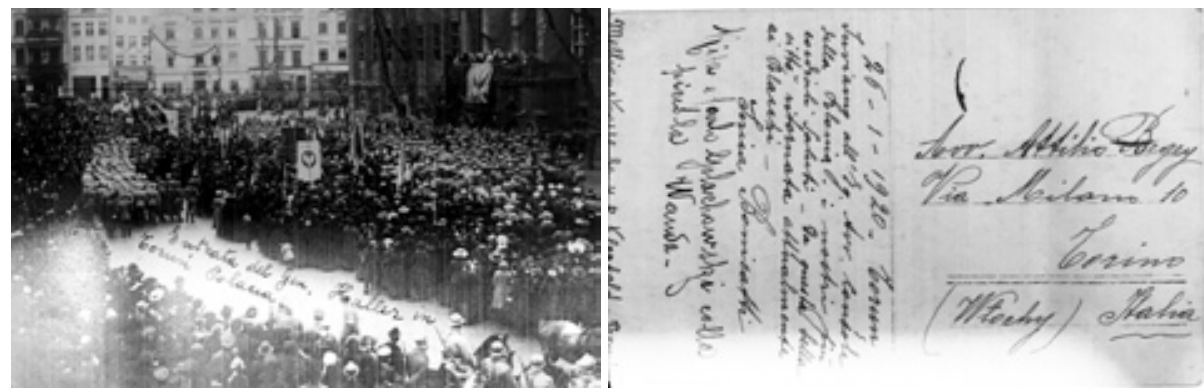

Pocztówka S. Bonicatti do A. Begeya, Toruń 26 stycznia 1920

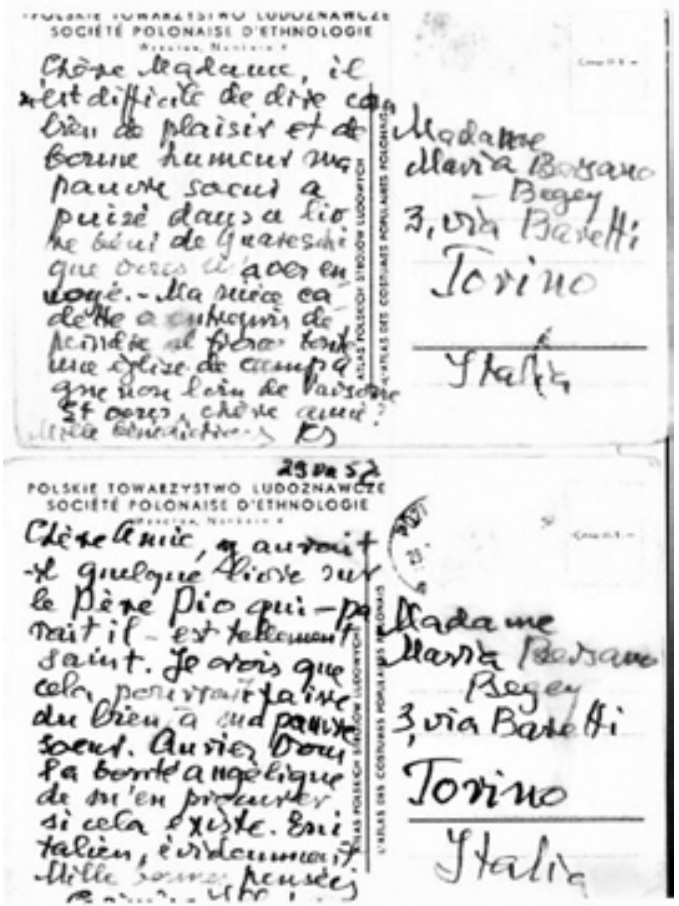

Pocztówki K. Iłłakowiczówny do M. Bersano Begey, [Poznań], b.d. i 29 Lipca 1957 
Krystyna Jaworska, Brakujące kartki. Kłopoty z biografistyką emigracyjną...

\section{Bibliografia}

Jaworska K., "Żołnierz polski we Włoszech" - polskie czasopismo w Piemoncie w 1919 roku, „Postscriptum” 2007 /1 (53).

Kozarynowa Z., Nakarmione dzieci, „Tydzień Polski”, 06.06.1982.

Kuba M., Skazane na nieobecność, „Rzeczpospolita” 2019, nr 203.

Kuciel-Frydryszak J., Iłła. Opowieść o Kazimierze Iłłakowiczównie, Warszawa 2017.

Marzec L., Archiwum jako pisarski testament i depozyt legendy biograficznej, „Teksty Drugie" 2018, nr 6, s. 231-248.

Sierpowski S., Powstanie Armii Polskiej we Włoszech w czasie pierwszej wojny światowej, „Roczniki Historyczne” 1976, XLII.

Skrzypek J., Tygodnik «Żołnierz polski we Włoszech» w 1919 r., „Rocznik Historii Czasopiśmiennictwa Polskiego" 1972, XI, nr 1.

Sokołowski M., Adwokat diabła Attilio Begey, Warszawa 2012.

Wal A., Wierna życiu i literaturze: o pisarstwie Herminii Naglerowej, Rzeszów 2014.

Ziemba K., Projekt komparatystyki wewnętrznej, „Teksty Drugie” 2005, nr 1-2, s. $72-82$. 